The unblushing effrontery of the implication of originality is attested not only by the similarity of the shape and construction of the boxes, but also by a comparison of the wording, spacing and style of type selected for the labels and of which $I$ present samples.

There is no reason why Mr. Gibson or any one else should not manufacture, sell or use these boxes, but the attempt to secure a patent on the ideas of another which have been public property for many years, and the use of a motto, "patent applied for," in order to scare off others from the free production of these boxes is to my mind, and I believe the medical profession at large will agree with me, an encroachment of commercialism which should not pass unheeded.

T. Stuart Hart, New York City.

130 West 59th Street.

\section{Mental Treatment by Physicians}

To the Erditor:-It is time for the medical profession and the ministry thoroughly to awake to the fact that Eddyism has spread because it in some measure satisfies a want. There is beneath its superstructure of falsity a fundamental truth, the power of faith, which draws people to it with the promise of cure. Some appreciative representatives of the Episcopal Church invented the Emmanuel movement as a cure for the evil of so-called "Christian Science," but the cure, to be successful, is too much like the disease. Its method of application, also, is too complex. The economic principle of the division of labor, whereby an individual's body is treated by a physician and his mind by a minister is not in this case conducive to thoroughness and effectiveness. It is, furthermore, supposititious and false to think that the clergy are by nature and calling better able to treat the mind than are other men. Although ministers as a body have studied mental science, only comparatively few of them are qualified to treat mental conditions. The number of medical men thus qualified is not great.

The idea is rather prevalent that all forms of mental treatment are fakes. Of course, many of them are. But in our own individual mental spheres do we all resign ourselves unreservedly to the theories of determinism, even of fatalism? Do we not practice mental treatment on ourselves by controlling, to greater or lesser degree, our mental content and our actions? Do we not unquestionably influence, also, the mental condition of others? And do we not voluntarily allow our mental condition to be influenced in varying degrees by others?

The fake cure cults, especially "Christian Science," are filled with people who are mentally sick. Any doctor who attends one of their experience meetings will be appalled by the ehimerical and delusional character of their stories. They find relief in the suggestion that belief in the non-existence of their trouble makes it non-existent, be the complaint in the spiritual or material sphere. The idea works, of course, within a much smaller scope than they claim.

Now, there can be no question that the mind acts on the body, that the body reacts on the mind, and, as now especially concerns us, that the mind acts on the mind. Is it not illogical, therefore, that the treatment of the mental and of the physical aspects of life should be carried out by two different professions? Every physician should realize that his duty is to examine and to treat the whole being, mind as well as body. Most cases that require mental treatment require at the same time some form of medical treatment and supervision, and should, therefore, be under the care of one who is capable of attending the whole being. The practice of medicine should extend into the mental life of ailing humanity. Not only so-called physical pain, but also mental discomfort and deviation should bring the patient to the doctor. The intimate relation thus established would increase the influence and dignity of our profession, and enhance the well-being of humanity. Then would be restored to the profession the attribute of sanctity which was in earlier days regarded as in herent to it, and this sanctity would rest on a firm scientific basis. To these ends the medical colleges should require their students to be familiar with psychology, ethics, logic, the principles of philosophy, and psychiatry.
But how shall the need of people for religious exercise be supplied if they are to receive mental treatment from physicians? "Christian Science" and, to a great extent, the Emmanuel movement combine religion with mental treatment and, in fact, their treatment may be said to consist largely of the practice of religion, thus opening the mind to new influence. If in attempting to remove the existing evils, we are, as we should be, scientific, let us be so consistently scientific as to be religious and to advise patients to practice religion. Religion is an instinct, the exereise of which yields mental benefits. For example, the first product of a sincere, devout prayer made with concentrated thought is a frame of mind that will prepare one for the thing expected. Every person, be he savage or eivilized, has the instinct of religion. And every mind, normal or pathologic, should modify itself with the benign influence of some rational, honest, sincere religion, for it is often the sheet-anchor of personality.

George Edward Barnes, M.D., Herkimer, N. Y.

The Combined Course for the Degrees of A.B. or B.S. and M.D.

To the Editor:-The ideas advanced by Dr. J. M. Dodson in The Journal, May 22, on a combined course leading to the degree of B.A. or B.S., with M.D., are in the right direction. The four years of college work after the high school should include medical subjects for the student intending to study medicine; this preparation should be credited toward his B.A. or B.S. degree. The student should be allowed to take a final examination on his medical studies before the state boards when he has finished the college course, and should receive credit for them.

The universities and colleges, when properly equipped, can give the first two years of the medical course as well as the average medical college or better. The course should comprise the study of anatomy with the dissection of the human body, chemistry, physiology, pathology, embryology and bacteriology. The instruction, always as practical as possible, should continue throughout the entire year with short intermissions every three or four months. I would divide the profession into physicians, surgeons, oculists and dentists; I would arrange courses of study to meet the needs of each division and would graduate the student into one or another of these four divisions. Dentists are graduated as specialists now; oculists might be; but in both cases the arrangement of studies can not be entirely satisfactory, as students are required to spend, on studies useless to them, time which might be better spent in practical work. The work of surgeons and physicians is more closely related, but still presents great differences.

The suggested arrangement of studies would not prevent a student from graduating in more than one class of the profession, but would encourage a more thorough preparation in the special line chosen. The practice of permitting the recent graduate in general medicine to treat the severe cases of the eye or ear or to perform difficult operations in surgery without more special prepalration has tended to discredit the profession and to harm the patient. We are trying to teach too much for thoroughness, and to force all students to one standard without regard to natural ability; we attain only a smattering in much and perfection in nothing. The fields of surgery and pathology have increased greatly in recent years and bacteriology is a new study. Our present system of education, formerly sufficient to the demands of the times, is based on conditions now antiquated or obsolete. Medicine now is too large a field for any one to be proficient in all its departments. John Binnie, Poynette, Wis.

\section{Reorganization of State Charities in Illinois}

To the Editor:-In the report of the Committee on Medical Legislation of the American Medical Association at the Atlantic City session, I notice the following from Illinois: "A most excellent bill reorganizing the state charitable, eleemosynary and corrective institutions and placing them all in the hands of a state board of administration, was introduced, but failed to become a law." The measure above re. ferred to, after having been previously passed by the House, passed the Senate during the last night of the session, and 
has since been signed by the governor. The board created by this act is to be non-partisan and to consist of five membors, but will not have control over corrective institutions.

L. C. TAYLoR, Springfield, Ill.

Chairman Committee on Medical Legislation, Illinois Medical Society.

\section{A Misquotation from Bishop Fallows Acknowledged}

To the Editor:-In an article entitled, "The General Practitioner and the Functional Nervous Diseases," published in The Journal (Jan. 9, 1909, lii, 87) I quoted some sentences from "Health and Happiness" by Samuel Fallows, D.D. These sentences were taken from the New York Evening Sun, in which they appeared in quotation marks. Bishop Fallows has written to me to say that the sentences making up the quotation are taken from various portions of his book; that is, they are taken out of the proper context. I regret that I did not verify the quotation before the article was published.

Josep' Colins, New York.

\section{Queries and Minor Notes}

Avonymous Communications will not be noticed. Queries for this column must be accompanied by the writer's name and address, but the request of the writer not to publish name or address will be faithfully observed.

\section{DISPOSAL OF GARBAGE AND FILTRATION OF WATER-} SUPPLY

To the Editor:-Please tell me where I can obtain any information, applicable to a city of 30,000 inhabitants, in regard (1) to modern methods of garbage disposal, and $(2)$ to city filtration of
water-supply.

$$
\text { City Health Commissioner, Rock Island, III }
$$

Axswer.-1. Modern methods of garbage disposal are clearly de scribed in two papers in the Transactions of the American Publio Health Association for 1901 (Vol, xxvii). These are "Refuse D:sposal in Boston," by H. W. Hill, p. 186, and "Refuse Disposal in the District of Columbia," by W. C. Woodward, p. 194. An especially raluable summary a!so appears in the same publication for 1903 (Vol. xxix), entitled "Some Statisties of Garbage Disposal for the Larger American Cities in 1902," by C-E. A. Winslow and P. Hansen. The last named paper gives valuable data regarding cost in this country and abroad, a bibliography of 27 titles, and a classified list of cities using different processes (further information could doubtiess be obtained from the municipal authorities if desired). The facts stated in the papers cited seem to justify the conclusion. "that separation of waste materials is neither economical nor desirable, that the cremation of mixed refuse appears to be the most generally satisfactory process and that this cremation may be best accomplished in furnaces of the English type."

2. Three of the best books in English on water filtration are "The Filtration of Water-Supplies," by Allen Hazen, "Clear Water and How to Get It," by the same author, and "Water and Its Purification," by Samuel Rideal. The two first-named are published by John Wiley and Sons, the last by J. B. Lippincott; all are procurable through your local booksellers.

STEREOSCOPY WITHOUT A STEREOSCOPE

To the Editor:-It occurred to me that stereoscopic lllustrations of steps in operative procedures, tumors, ete., could be more generally used than they are now. I have noticed that, with only a little practice, one can get the stereoscopic effect from a stereoscopic illustration, without the use of a stereoscope. Hold the stereogram before the eyes at a distance of 12 to 26 inches; look at the white perpendicular line up the middle; gazing not too fixedly at this line, endeavor to lose your accommodation, when, if you persist, a dissolving effect takes place and the single object stands out clear in perspective. The use of such illustrations in our journals and surgical works has many obvious advantages and
will appeal to every scientific and sound-eyed physician. This is merely a practical application of an old physiologic fact IvaN I. YoDER, M.D., Cleveland, Ohio.

\section{THE CAMMIDGE REACTION} To the Editor:-Please give information in regard to the pan-
creatic reaction of Cammidge.
R. H. MiNer, Windsor. vt.

ANSWER.-The pancreatic reaction of Caminidge was described in The Journal, Aug. 22, 1908, li, 691. Opinions are still divided as to its clinical value, although the bulk of evidence is in favor of the view that, while it is not pathognomonic, it is a valuable diagnostic ald.

\section{The Public Service}

\section{Army Changes}

Memorandum of changes of stations and duties of medical officers,

Schmitter, Ferdinand, 1st lieut., ordered to St. Louis, Mo, for emporary duty in charge of the Medical Supply Depot.

Truby, Albert E., major, ordered to take charge of chief surgeon office, San Francisco, Cal., during the absence of Major James M. Kennedy on inspection tour.

Dale, Frederick A., capt., granted leave of absence for 14 days. Foster, Charles L., capt., ordered from San Francisco, Cal., to Washington, D. C., in charge of an escort to insane patients.

Perley, Harry O., col., announced as chief surgeon, Department of the Colorado; ordered to inspect posts in that department.

Kiersted, Henry S., capt., granted leave of absence for 1 month. Chamberlain, Weston P., noajor, detailed a member of the board of medical officers for studying tropical diseases in Philippine lands.

Foster, Charles L., capt., granted leave of absence to July 6 .

O'Day, Sylvester F., 1st Iieut., M.R.C., honorably discharged from the service of the United States, his services being no longer

Buchsbaum, Maurice, 1st lieut., M.R.C., ordered to duty with troops marching from Fort $D$. A. Russell, Wyo., to Fort Robinson, eb., instead of 1st Lieut. Joseph E. Bastion, M.R.C.

Tyler, George T., 1st lieut., M.R.C., relleved from duty at time to.sail August 5 th for the Philippine Islands.

Kierlos August 5th for the Philippine Islands. Minn. July 2 , for temporary duty.

McMillan, Clemons W., 1st lieut., M.R.C., granted leave of absence for 2 months, August 20 .

Fisk, Owen C., 1st lieut., M.R.C., ordered to Fort Michle, N. Y., for temporary duty during the week beginning July 12 .

McCown, Thomas B., 1 st lieut., M.R.C., ordered to Fort Duchesne, Utah, for temporary duty during the week beginning July 12 .

Pomeroy, William H., contract surgeon, granted leave of absence for 21 days.

Graig, Emmett J., dent.-surg., ordered to Fort Des Moines, Iowa, for 1 month, and thence to Fort Riley, Kan. for 3 months.

Ryan, Edward P. R., dent.-surg., ordered to Fort Mackenzie, Wyo. for 20 days, and thence to Fort D. A. Russell, Wyo. for 2 months. Boak, S. Davis, dent.-surg., ordered from vancouver Barracks, Wash., to Fort Lawton, Wash., for duty.

Voorhies, Hugh G., dent.-surg., relieved from duty at Fort Snelling, Minn, and ordered to Jefferson Barracks, Mo., for duty. Ames, John $R$., dent.-surg., relieved from duty at Jefferson Barracks, Mo., and ordered to Fort Snelling, Minn., for duty. Whinnery, Jean C., dent.-surg., arrived at Fort Egbert, Alaska,
for duty.

\section{Navy Changes}

Changes in Medical Corps, U. S. Navy, for the week ended June

Williams, R. B., surgeon, commissioned surgeon from Dec. 11,

Kennedy, R. M., surgeon, ordered to command the naval hospital, San Juan, P. R., sailing from New York, N. Y., about July 24.

Johnson, M. K., surgeon, detached from the Naval Training
Station, Narragansett Bay, R. I., July 10 and ordered to the South Dakota.

Von Wedekind, L. L., surgeon, detached from the South Dakota and ordered home to await orders.

Grove, W. B., surgeon, detached from the Minnesota and ordered to the Naval Training Station, Narragansett Bay, $R$. I.

Alfred, A. R., surgeon, detached from the Wolverine and ordered to the Minnesota.

Dunn, H. A., P. A. surgeon, detached from the Independence, ordered home and granted leave for 2 months.

Webb, U. R. P. A. surgeon, detached from the Naval Hospital, San Juan, P. R., and ordered home to wait orders.

Munger, C. B., asst.-surgeon, ordered to the Naval Training

Robnett, A. H., asst.-surgeon, ordered to duty at Naval Hospital,

Steadman, W. G., asst.-surgeon, detached from the Louisiana and ordered to continue treatment at the Naval Hospital, Nor-

Reed, A. U., asst.-surgeon, ordered to Naval Recruiting Station,

Cohn, I. F., asst.-surgeon, ordered to duty at the Naval HosThiladelphia. Woods, E. L., asst.-surgeon, ordered to duty at the Naval Hos-
pital, Annapolis, Md. Olson, G. M., asst.-surgeon, ordered to the Naval Recruiting
Station, Minneapolis.

Shippen, L. P., asst.-surgeon, detached from the Naval Recruiting Station, Minneapolis, and ordered to the Navy Yard, Mare Island, Giltner, H. A., asst.-surgeon, detached from the Naval Training Station, San Francisco, and ordered to the Glacier.

Eytinge, E. O. J., asst.-surgeon, ordered to the Wolverine.

Riker, C. A., asst.-surgeon, detached from the Franklin and ordered to the Louisiana.

Thomas, G. E., acting asst.-surgeon, detached from duty at the Whos

Wheeler, L. H., P. A. surgeon, detached from the Hancock and ordered to the Mariet

Brister, J. M., P. A. surgeon, detached from the Milnoaukee and dered to the Independence.

Jenness, B. F., P. A. stirgeon, detached from the Glacier and ordered to the Milwaukee and to additional duty at the Naval
Hospital, Puget Sound, Wash. 